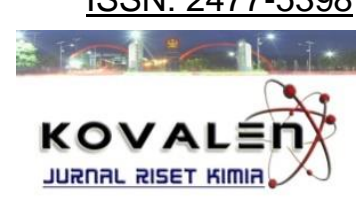

\title{
PENGGUNAAN SELULOSA-DIETILENTRIAMINA SEBAGAI LAPISAN PENGIKAT LOGAM Cu(II) DENGAN METODE GRADIEN DIFUSI DALAM FILM TIPIS
}

\section{[Application of Cellulose-Diethylenetriamine as a Binding Layer of $\mathrm{Cu}$ (II) on The Diffusive Gradients in Thin Films Method]}

\author{
Khairuddin $^{{ }^{\star}}$, Dwi Juli Puspitasari ${ }^{1}$ \\ ${ }^{1}$ Jurusan Kimia FMIPA Universitas Tadulako Palu \\ Jl. Soekarno Hatta, Kampus Bumi Tadulako Tondo Palu, Telp. 0451- 422611
}

Diterima18 Oktober 2016, Disetujui 23 November 2016

\begin{abstract}
This researh aims to application of cellulose-diethylenetriamine as a binding layer on the diffusive gradients in thin films method with modification of cellulose with diethylenetriamine. The method of diffusive gradients in thin films in principle uses a simple instrument such as round plastic with a diameter of $2.5 \mathrm{~cm}$, which is filled with metal binding gel, diffusive gel, and membrane filter of $0.45 \mu \mathrm{m}$. The metal ions were diffuse through the membrane filter and diffusive gel according to the Fick's Law I, and then is accumulated in the binding layer gel. Based on the results of FTIR analysis, the formation of the binders of the copper ions at the binding layer of cellulose-dietilentriamina involves amine and hydroxyl functional groups. The results of the application of cellulose- diethylenetriamine using as binding layer with polyacrylamide diffusive gel showed a liniar concentration up to 12 hours of contact time and initial copper ion concentration up to $1000 \mathrm{mg} / \mathrm{L}$. The maximum concentration of copper was obtained at $\mathrm{pH} 4$.
\end{abstract}

Keywords: copper, cellulose- diethylenetriamine, polyacrylamide gel.

\begin{abstract}
ABSTRAK
Penelitian ini bertujuan untuk aplikasi selulosa-dietielentriamina sebagai lapisan pengikat pada metode gradien difusi dalam film tipis melalui tahapan modifikasi selulosa dengan dietilentriamina, dan pengujian kinerja selulosa-dietielentriamina. Metode difusi gradien dalam film tipis pada prinsipnya menggunakan peralatan sederhana berupa plastik bulat dengan diameter $2,5 \mathrm{~cm}$ yang diisi dengan gel lapisan pengikat, gel difusi, serta filter membran 0,45 $\mu \mathrm{m}$. Ion logam berdifusi melewati filter membran dan gel difusi sesuai Hukum Fick I dan terakumulasi pada gel lapisan pengikat. Berdasarkan hasil analisis FTIR, terjadinya pengikatan ion tembaga pada lapisan pengikat selulosa-dietilentriamina melibatkan gugus fungsi amina dan hidroksil. Hasil penelitian melalui aplikasi lapisan pengikat pada metode gradien difusi dalam film tipis dengan gel difusi poliakrilamida menunjukkan konsentrasi tembaga bertambah secara linear hingga waktu kontak 12 jam, dan konsentrasi maksimum tembaga diperoleh pada konsentrasi awal larutan 1000 $\mu \mathrm{g} / \mathrm{L}$ sementara pengujian variasi $\mathrm{pH}$ menunjukkan nilai maksimum pada $\mathrm{pH} 4$.
\end{abstract}

Kata kunci : tembaga, selulosa-dietilentriamina, gel poliakrilamida.

*) Coresponding Author : heru_jns@yahoo.co.id 


\section{LATAR BELAKANG}

Pencemaran lingkungan selalu menjadi masalah serius, terutama mengenai pencemaran logam berat. Tidak seperti beberapa polutan organik, logam berat dianggap agen polusi paling berbahaya dalam air karena bioakumulasi dan tidak terurai dan bisa tinggal untuk waktu yang lama di lingkungan alam (Chethan \& Vishalakshi, 2015).

Jumlah logam berat yang dihasilkan dari industri logam, kegiatan pertanian dan pembuangan limbah telah meningkat secara dramatis. Jika tingkat ion logam berada di luar batas toleransi, maka akan menimbulkan masalah kesehatan masyarakat dan lingkungan yang serius. Akibatnya, pengembangan teknik yang efektif untuk memonitor ion logam beracun dari air limbah dan air permukaan (sungai, laut) sangat penting untuk memantau kualitas air.

Peningkatan kadar logam berat dalam air laut yang terus berlangsung akan diikuti oleh peningkatan kadar logam berat dalam tubuh biota, yang berakhir dengan timbulnya pencemaran. Timbal $(\mathrm{Cu})$ merupakan salah satu logam dalam sistem perairan dan dijumpai baik sebagai ion bebas maupun dalam bentuk kompleks dengan bahan organik terlarut. Logam ini penting dimonitoring dalam sistem perairan karena mudah menjadi toksik pada tingkatan $10-50$ dari konsentrasi normal yang dibutuhkan untuk pertumbuhan organisme dan biota air (Shaaban et al., 2014; Ahmad et al., 2012)

Oleh karena pencemaran di perairan akibat logam berat tersebut tidak dapat dibiarkan begitu saja, karena bila tidak dilakukan pengendalian sejak dini dapat memberikan dampak yang sangat buruk terhadap kelangsungan hidup biota laut dan makhluk hidup sekitarnya maka perlu dilakukan monitoring dan pengukuran kadar logam berat di lingkungan khususnya pada lingkungan perairan walaupun pengukuran logam runut dalam sistem perairan relatif sulit untuk dilakukan.

Pendekatan baru untuk pendugaan pencemaran logam berat dan status ekotoksikologi lingkungan perairan adalah dengan metode sampling menggunakan metode gradien difusi dalam film tipis (Diffusive Gradient in Thin Films) (Scally et al., 2006; Dahlqvist et al., 2002; Denney et al., 1999). Metode ini mulai pertama kali dikembangkan oleh Bill Davison dan Hao Zhang sejak tahun 1993 di Lancaster, Inggris dan dipatenkan oleh Lancaster University. Teknik ini ditetapkan sebagai teknik prekonsentrasi in-situ dan merupakan metode passive sampling yang sesuai untuk mengukur spesi labil yang terakumulasi di lingkungan akuatik. Pada prinsipnya DGT terdiri dari suatu alat sederhana terbuat dari plastik berbentuk bulat dengan diameter 2,5 $\mathrm{cm}$ yang dapat diisi dengan lapisan 
pengkelat logam dan hidrogel sebagai lapisan difusi serta membran filter 0,45 $\mu \mathrm{m}$. Hidrogel poliakrilamida adalah jaringan polimer tiga dimensi yang sangat hidrofilik namun tidak larut dalam air. Ketika sepenuhnya terhidrasi, hidrogel dapat terisi lebih dari $95 \%$ air. Sifat lain dari hidrogel yang menarik adalah kapasitasnya untuk memungkinkan difusi yang terkendali, respon pembengkakan (swelling) terhadap perubahan konsentrasi ion, $\mathrm{pH}$, suhu, dan kemampuannya untuk berinteraksi dengan spesi kimia (misalnya $\mathrm{Cd}, \mathrm{Cu}, \mathrm{Cr}, \mathrm{Hg}$ ) melalui gugus-gugus polar yang bertanggung jawab untuk sifat hidrofilik logam tersebut.

Dalam air laut, logam berat terdapat dalam bentuk logam terlarut dan tersuspensi. Kedua bentuk ini dapat dipisahkan melalui penyaringan dengan menggunakan membran filter yang berukuran pori 0,45 $\mu \mathrm{m}$. Ion berdifusi melalui filter membran dengan cara pembentukan gradien konsentrasi yang konstan sehingga terkumpul pada lapisan pengkelat (binding layer) yang menjadi dasar untuk mengukur logam dalam larutan secara kuantitatif. Massa logam pada lapisan pengkelat diukur setelah dielusi dengan larutan asam (Dunn et al., 2007). Konsentrasi spesi analit yang diikat lapisan pengkelat logam DGT dianggap sama dengan konsentrasi yang berdifusi ke biota akuatik sehingga metode ini juga dapat memprediksi bioavailabilitas spesi-spesi anorganik labil seperti logam, fosfat, dan sulfida.

Perangkat DGT terdiri dari tiga lapisan yaitu gel lapisan pengkelat logam, gel lapisan difusi dan filter membran. Filter membran berfungsi untuk memisahkan partikel tersuspensi pada peristiwa difusi. lon logam labil dalam larutan akan berdifusi melalui filter membran dan lapisan difusi hingga akhirnya diprekonsentrasi pada gel pengkelat logam (Mojsilovic et al., 2011; Czaja et al., 2004).

Analit berdifusi dari larutan sampel melalui lapisan difusi kemudian diadsorbsi pada lapisan pengikat. Dengan demikian gradien konsentrasi pada lapisan difusi hingga konsentrasinya sama dengan konsentrasi pada larutan sampel. Massa logam dikumpulkan oleh gel pengkelat dari larutan logam menurut Persamaan ( 1 ).

$$
\mathrm{C}=(\mathrm{M} . \Delta \mathrm{g}) /(\text { D.t.A })
$$

di mana $C$ adalah konsentrasi logam dalam fasa ruah, M massa logam dalam gel Chelex, $\Delta \mathrm{g}$ ketebalan lapisan difusi, D adalah koefisien difusi ion logam dalam lapisan difusi, $\mathrm{t}$ adalah waktu kontak dan $\mathrm{A}$ adalah luas permukaan kontak.

Massa logam dikumpulkan oleh lapisan pengkelat dihitung setelah elusi dalam $\mathrm{HNO}_{3} 1 \mathrm{M}$ menurut persamaan (2).

$$
\mathrm{M}=\frac{C_{e}\left(V_{g}+V_{e}\right)}{f_{e}}
$$


dimana Ce adalah konsentrasi logam dalam eluen, $\mathrm{V}_{\mathrm{g}}$ dan $\mathrm{V}_{\mathrm{e}}$ masing-masing volume gel dan eluen, dan $\mathrm{f}_{\mathrm{e}}$ adalah faktor elusi.

Berbagai fasa padat termasuk polimer dan bahan anorganik telah digunakan sebagai sorben selektif untuk menghilangkan ion-ion logam. Hingga kini berbagai teknologi telah dikembangkan untuk menghilangkan polutan logam dari limbah cair. Ini termasuk metode seperti presipitasi, elektrodialisis, elektroplating, pertukaran ion, proses membran, biosorpsi dan sebagainya. Setiap metode memiliki keterbatasan dalam hal penghilangan ionion logam dan toleransi yang terbatas terhadap perubahan $\mathrm{pH}$.

Dalam penelitian ini, diteliti hasil modifikasi selulosa dengan dietilentriamina untuk digunakan sebagai lapisan pengikat logam untuk pengukuran timbal.

\section{METODE PENELITIAN}

\section{Bahan dan Peralatan}

Selulosa, Akrilamida, air bebas mineral, Bis-akrilamida, Amonium persulfat $\left(\mathrm{NH}_{4} \mathrm{~S}_{2} \mathrm{O}_{8}\right), \quad \mathrm{N}, \mathrm{N}, \mathrm{N}^{\prime} \mathrm{N}^{\prime}$-Tetrametiletilen diamina (TEMED), membran selulosa nitrat 0,45 $\mu \mathrm{m}, \mathrm{NaNO}_{3}, \mathrm{NaOH}, \mathrm{HNO}_{3}$.

Beberapa alat yang digunakan antara lain : Perangkat DGT (DGT Research Lancaster University, Inggris), instrument FTIR, dan Atomic Absorption Spectrophotometer, $\mathrm{pH}$ meter, timbangan analit.

\section{Prosedur Penelitian}

\section{Sintesis lapisan Pengkelat Logam Selulosa-Dietilentriamina}

Serbuk selulosa direndam dalam larutan $\mathrm{NaOH} 15 \%$ selama satu jam pada temperatur kamar yang dilanjutkan dengan pencucian dengan air mengalir. Selulosa sebanyak 1 gram lalu diletakkan dalam gelas kimia dengan magnetik stirrer dan ditambahkan epiklororohidrin sebanyak 3 $\mathrm{mL}$ dan $100 \mathrm{~mL}$ larutan $\mathrm{NaOH}$ 8\%. Reaksi dilakukan selama 10 jam sambil diaduk dengan magnetik stirrer. Produk hasil reaksi dicuci dengan air bebas mineral dan etanol anhidrat hingga $\mathrm{pH} 7,0$ lalu dikeringkan pada temperatur $60^{\circ} \mathrm{C}$. Produk hasil reaksi sebanyak 1 gram dicampurkan dengan 1 gram dietilentriamina dan $100 \mathrm{~mL}$ air bebas mineral dan sedikit $\mathrm{NaHCO}_{3} 10 \mathrm{M}$ sebagai katalis sambil terus diaduk pada temperatur $50^{\circ} \mathrm{C}$ selama 2 jam. Produk yang dihasilkan dicuci dengan air dan etanol anhidrat hingga $\mathrm{pH}$ 7,0 dan selanjutnya dikeringkan pada temperatur $60^{\circ} \mathrm{C}$.

\section{Karakterisasi Gugus Fungsi}

Selulosa dan selulosa teraminasi dietilentriamina dikarakterisasi pada bilangan gelombang $450 \mathrm{~cm}^{-1}$ sampai dengan $\quad 4000 \mathrm{~cm}^{-1}$ dengan spektrofotometer FTIR. Penyiapan cuplikan dilakukan dengan metode pellet $\mathrm{KBr}$.

\section{Pembuatan Gel Difusi}

Pembuatan gel poliakrilamida sebagai gel difusi ion mengikuti prosedur yang 
digunakan oleh Morford et al., (2003). Campuran gel monomer akrilamida $(6 \%)$ dan cross linker bis-akrilamida $(0,8 \%)$ direaksikan dengan tetrametiletilena diamin (TEMED), dan katalis amonium persulfat (10\% larutan) untuk membuat gel poliakrilamida. Larutan gel disiapkan melalui pencampuran akrilamida dan cross-linker bis akrilamida. Polimerisasi dimulai dengan menambahkan $6 \mu \mathrm{L}$ amonium persulfat dan 2,5 $\mu \mathrm{L}$ tetrametiletilendiamina (TEMED) per mililiter larutan gel. Larutan gel yang dihasilkan lalu diletakkan pada cetakan kaca $0,78 \mathrm{~mm}$. Setelah dikeluarkan, gel dihidrasi untuk membuat gel menjadi stabil. Gel kemudian dicetak dengan diameter 2,5 $\mathrm{cm}$.

\section{Pembuatan Gel Selulosa-Dietilentriamina} Sebanyak $0,2 \quad g \quad$ selulosadietilentriamina (100 mesh) ditambahkan permililiter larutan gel difusi. Polimerisasi gel melalui penambahan $6 \mu \mathrm{L}$ amonium persulfat dan $2 \mu \mathrm{L}$ TEMED permililiter larutan gel difusi untuk pembentukan gel selulosa- dietilentriamina. Gel kemudian dicetak dengan diameter $2,5 \mathrm{~cm}$ kemudian disimpan dalam 0,01 $\mathrm{M} \mathrm{NaNO}_{3}$ hingga akan digunakan.

\section{Pemasangan Perangkat DGT}

Untuk mengaplikasikan DGT, hal pertama yang dilakukan adalah menyiapkan unit DGT yaitu dengan cara meletakkan gel pengkelat logam selulosa- dietilentriamina, gel difusi poliakrilamida, serta membran selulosa nitrat secara berurutan seperti terlihat pada Gambar 1.

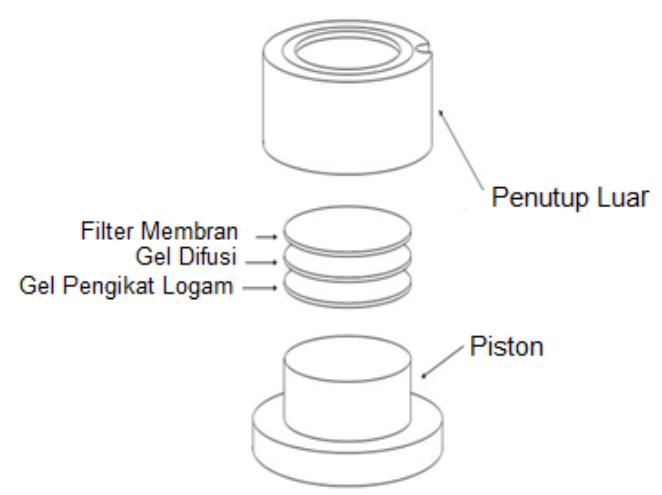

Gambar 1. Susunan filter membran $0,45 \mu \mathrm{m}$, gel lapisan difusi, dan lapisan pengkelat logam dalam probe DGT.

\section{Analisis Kinerja Metode DGT}

\section{a. Pengaruh Waktu Kontak}

Perangkat DGT diisi dengan gel selulosa- dietilentriamina, gel difusi lalu ditutup dengan filter membran 0,45 $\mu \mathrm{m}$. Pengujian variasi waktu kontak menggunakan $500 \mu \mathrm{g} / \mathrm{L}$ larutan $\mathrm{Cu}$ dalam $0,01 \mathrm{M} \mathrm{NaNO}_{3}$ dengan variasi waktu kontak 3, 6, 9, 12 jam. Pada setiap variasi waktu penggelaran, gel selulosa-dietilentriamina dalam perangkat DGT diambil dari larutan kemudian dielusi dengan $2 \mathrm{~mL} \mathrm{\textrm {HNO } _ { 3 }} 1 \mathrm{M}$ selama 24 jam lalu diencerkan hingga 10 $\mathrm{mL}$ dan kadar logam $\mathrm{Cu}$ dalam diukur dengan ICP-MS.

\section{b. Pengaruh Konsentrasi}

Pengaruh variasi konsentrasi dilakukan dengan cara membuat larutan $\mathrm{Cu}^{2+}$ dengan konsentrasi 400, 600, 800, dan $1000 \mu \mathrm{g} / \mathrm{L}$ dalam $0,01 \mathrm{M} \mathrm{NaNO}_{3}$ pada beaker glass 1 
liter. Perangkat DGT yang telah diisi dengan gel selulosa- dietilentriamina, gel difusi, dan membran filter dimasukkan dalam beaker dan diaduk meggunakan pengaduk magnetik selama waktu kontak berdasarkan hasil uji sebelumnya serta mencatat suhu larutan. Setelah waktu tertentu perangkat DGT diangkat dan dicuci dengan air bebas mineral dan gel dietilentriamina-selulosa (binding layer) yang ada dalam unit DGT dielusi dalam $2 \mathrm{~mL}$ larutan $\mathrm{HNO}_{3} 1 \mathrm{M}$ selama 24 jam dan diencerkan hingga 10 $\mathrm{mL}$. Kemudian diukur dengan menggunakan ICP-MS.

\section{c. Pengaruh $\mathrm{pH}$}

Larutan $\mathrm{Cu}^{2+}$ dengan konsentrasi 100 $\mu \mathrm{g} / \mathrm{L}$ dalam $0,01 \mathrm{M} \mathrm{NaNO}_{3}$ dengan volume larutan satu liter diatur pH-nya 2; 4; 6; dan 8. Pengaturan $\mathrm{pH}$ dilakukan dengan penambahan $\mathrm{HNO}_{3}$ dan $\mathrm{NaOH}$. Perangkat DGT dimasukkan pada masing-masing larutan tersebut selama waktu kontak optimum. Kemudian alat DGT yang telah diisi dengan gel selulosa- dietilentriamina, gel difusi, dan membran filter dimasukkan dalam beaker dan diaduk dengan pengaduk magnetik selama waktu kontak optimum, serta dicatat suhu saat peletakkan dan pengangkatan DGT. Setelah itu gel dielusi dalam $2 \mathrm{~mL}$ larutan $\mathrm{HNO}_{3} 1 \mathrm{M}$ selama 24 jam dan diencerkan hingga $10 \mathrm{~mL}$. Kemudian kadar $\mathrm{Cu}$ diukur dengan menggunakan ICP-MS.

\section{HASIL DAN PEMBAHASAN}

Pada sintesis selulosa- dietilentriamina, gugus hidroksil selulosa bereaksi dengan epiklorohidrin pada kondisi basa untuk memberikan derivat epoksi selulosa yang memudahkan reaksi dengan dietilentriamina. Skema re aksi sintesis selulosa - dietilentriamina seperti ditunjukkan pada Gambar 2.

Gambar 3 menunjukkan spektrum FTIR dari selulosa, selulosa dalam kondisi basa, epoksi selulosa dan dietilentriamina selulosa. Bilangan gelombang puncak utama terletak di sekitar $3446 \mathrm{~cm}^{-1}$ yang berasal dari - $\mathrm{OH}$ stretching. Pada senyawa selulosa-dietilentriamina puncak menjadi luas karena keberadaan gugus amina $\mathrm{NH}_{2}$. Bilangan gelombang $1029 \mathrm{~cm}^{-1}$ sesuai untuk C-O-C stretching juga diamati pada semua sampel.

Analisis kinerja gel pengkelat logam dietilentriamina - selulosa dalam larutan $\mathrm{Cu}^{2+}$ bertujuan untuk mengetahui apakah resin gel yang telah dibuat benar-benar mampu menyerap ion logam $\mathrm{Cu}$ dan mengetahui apakah dalam selang waktu, konsentrasi dan $\mathrm{pH}$ tertentu massa logam yang terserap masih memberikan serapan linier. Pada penelitian ini diperoleh nilai koefisien difusi $\mathrm{Cu}$ dalam gel poliakrilamida pada temperatur $30^{\circ} \mathrm{C}$ adalah $7,07 \times 10^{-6}$ $\mathrm{cm}^{2} \mathrm{~s}^{-1}$. 

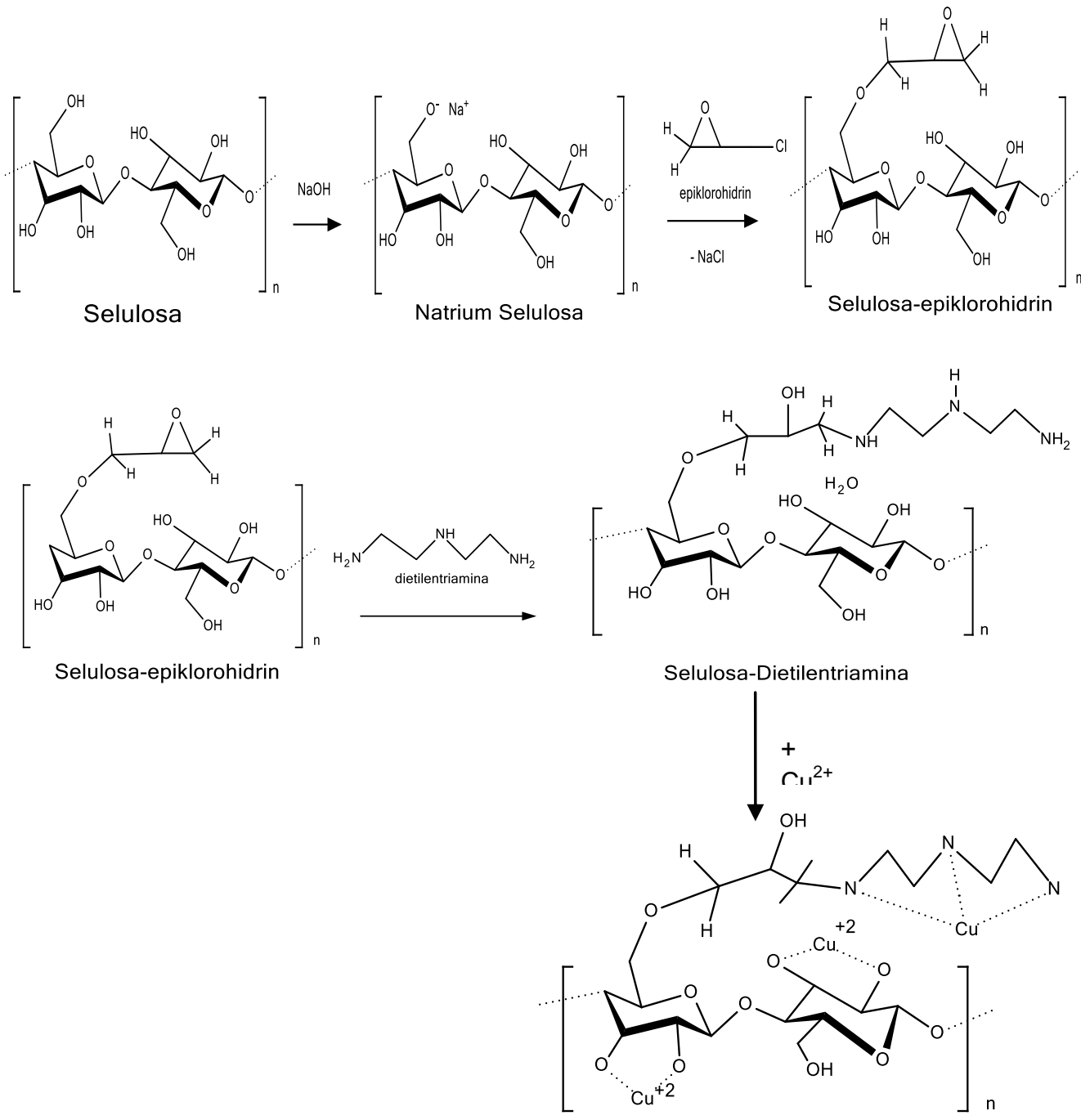

$\mathrm{Cu}(\mathrm{II})$-Selulosa-dietilentriamina

Gambar 2. Skema reaksi sintesis selulosa - dietilentriamina.

Pengaruh waktu kontak dilakukan untuk mengetahui waktu yang diperlukan oleh lapisan pengikat logam selulosadietilentriamina dengan gel yang difusi poliakrilamida dalam mengikat ion $\mathrm{Cu}(\mathrm{II})$ secara maksimal. Waktu berkaitan dengan laju reaksi dimana dinyatakan sebagai perubahan konsentrasi ion $\mathrm{Cu}$ (II) terhadap waktu. Semakin lama waktu kontak maka semakin banyak pula ion $\mathrm{Cu}(\mathrm{II})$ yang akan terikat ke dalam lapisan pengikat logam selulosa-dietilentriamina. Hal ini terjadi karena semakin lama waktu kontak maka driving force yang diberikan ion $\mathrm{Cu}(\mathrm{II})$ semakin banyak pula untuk mensubstitusi ion $\mathrm{H}^{+}$yang berada pada gugus hidroksil dan gugus amina semakin besar (Shen et al., 2009). 


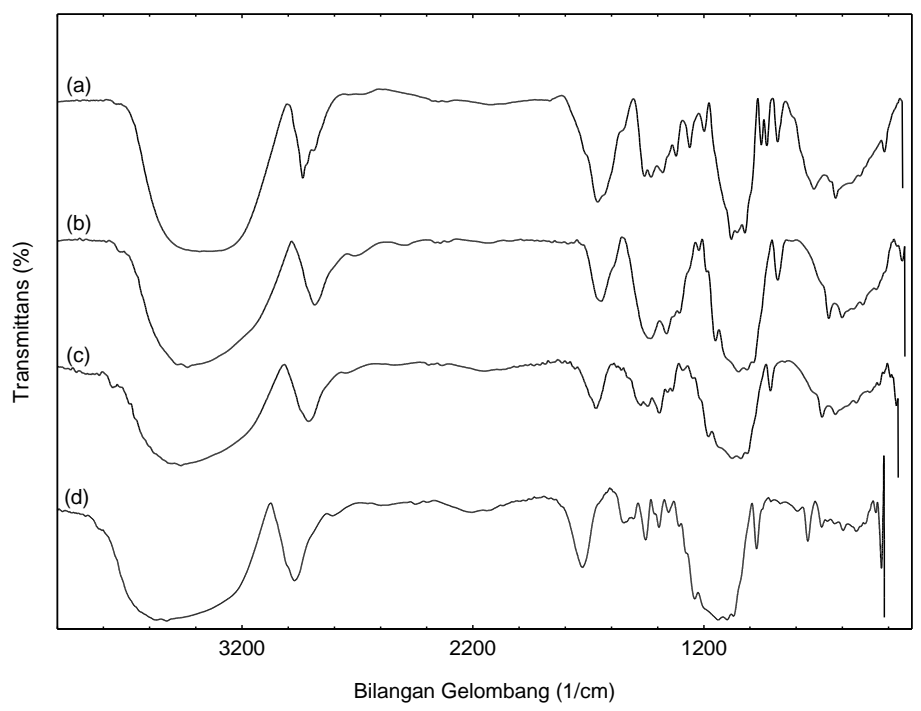

Gambar 3. Spektrum FTIR dari (a) selulosa, (b) natrium selulosa (c) epoksi selulosa (d) dietilentriamina selulosa.

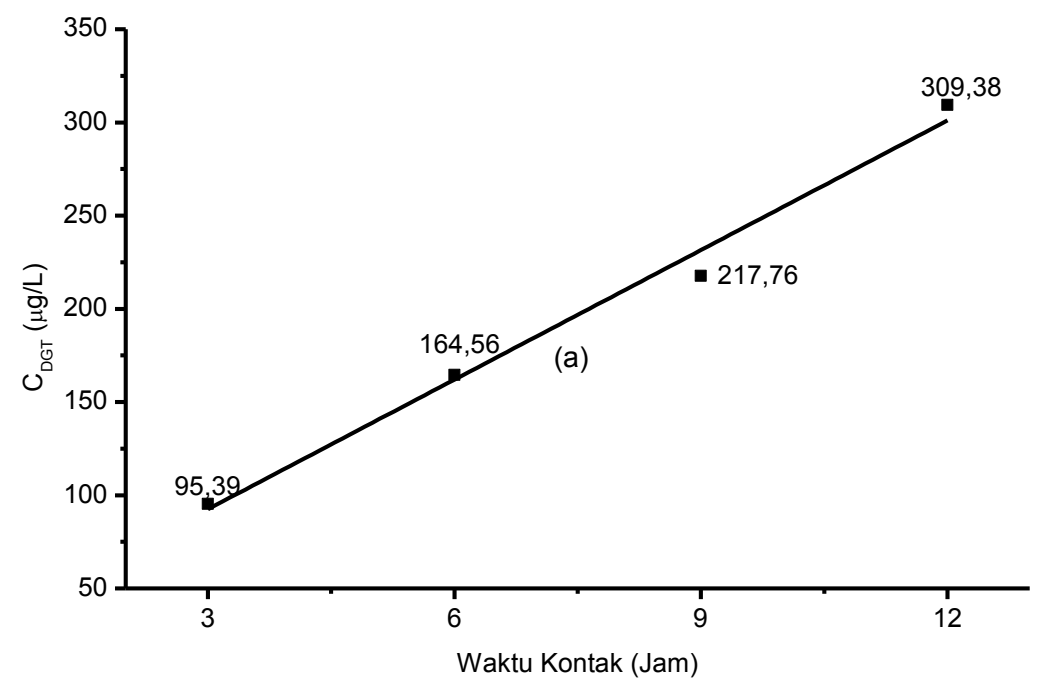

Gambar 4. Pengaruh Waktu Kontak Terhadap Konsentrasi Cu(II) yang Terikat pada Gel Selulosadietilentriamina dengan Lapisan Difusi Gel Poliakrilamida.

Gambar 4 menunjukkan bahwa konsentrasi $\mathrm{Cu}(\mathrm{II})$ pada waktu kontak 3 jam adalah 95,39 $\mu \mathrm{g} / \mathrm{L}$, bertambah hingga waktu kontak 12 jam dan diperoleh konsentrasi Cu(II) 309,38 $\mu \mathrm{g} / \mathrm{L}$.
Kinerja lapisan pengikat logam melalui pengujian pengaruh konsentrasi ini dilakukan untuk mengetahui pola pengikatan ion $\mathrm{Cu}(\mathrm{II})$ oleh lapisan pengikat selulosa-dietilentriamina melalui perlakuan 
variasi konsentrasi larutan awal kontak 12 jam pada temperatur $30^{\circ} \mathrm{C}$. Hasil $\mathrm{Cu}(\mathrm{II})$.Pengujian dilakukan pada konsentrasi pengujian dapat dilihat pada Gambar 5. 400, 600, 800, dan 1000 Mg/L dengan waktu

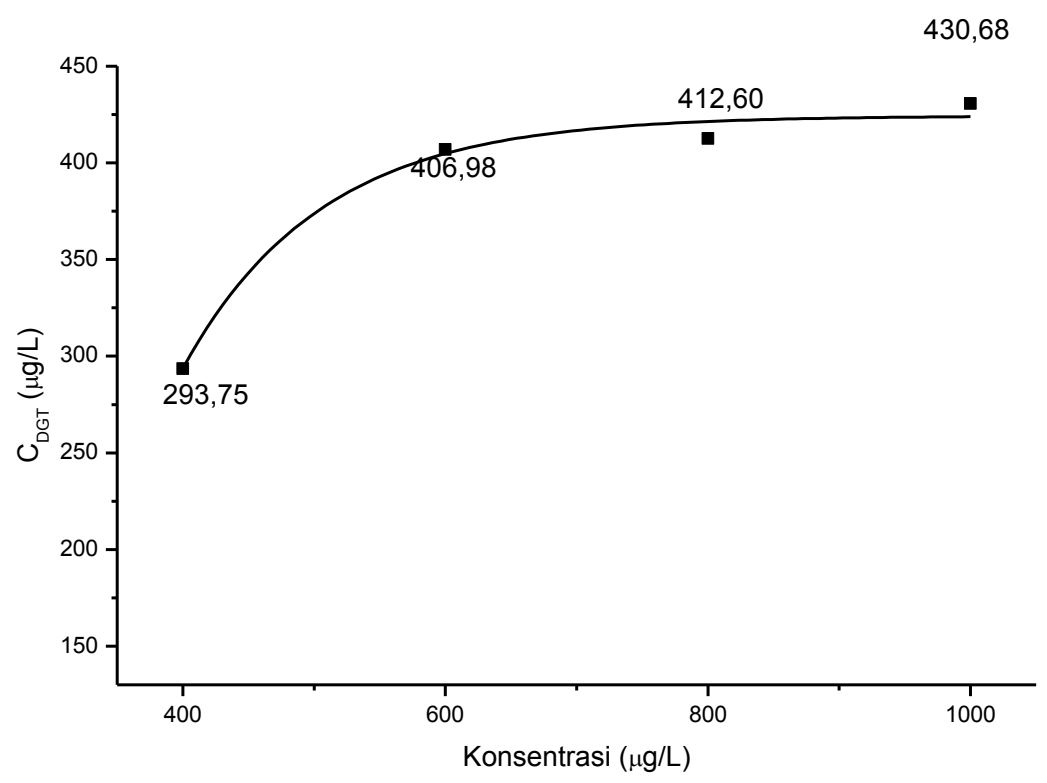

Gambar 5. Pengaruh Konsentrasi Awal Larutan Terhadap Konsentrasi Cu(II) pada Gel Selulosadietilentriamina dengan Gel Difusi Poliakrilamida.

Gambar 5 menunjukkan bahwa jumlah ion logam $\mathrm{Cu}$ terikat meningkat seiring dengan meningkatnya konsentrasi larutan awal Cu. Rerata konsentrasi Cu(II) pada lapisan pengikat (CDGT) dengan menggunakan lapisan difusi poliakrilamida diperoleh 293,75 $\mu \mathrm{g} / \mathrm{L}$ pada larutan awal arutan $\mathrm{Cu}$ (II) $400 \mu \mathrm{g} / \mathrm{L}$ dan mencapai nilai rerata konsentrasi tertinggi pada larutan awal Cu(II) 1000 Mg/L yakni sebesar 430,68 $\mu \mathrm{g} / \mathrm{L}$. Hal ini menunjukkan laju difusi berbanding lurus dengan peningkatan konsentrasi. Semakin besar perbedaan konsentrasi, semakin besar laju aliran molekul-molekul zat. Sebaliknya, semakin kecil perbedaan konsentrasi, semakin kecil laju aliran molekul-molekul zat.

Analisis kinerja lapisan pengikat logam selulosa-sietilentriamina juga diamati melalui pengujian $\mathrm{pH}$. Perubahan $\mathrm{pH}$ dapat mempengaruhi sifat kimia gugus aktif lapisan pengikat misalnya kelarutan dan muatan dari gugus fungsi lapisan pengikat (Li et al., 2002). Pengujian pengaruh pH terhadap kemampuan pengikatan logam $\mathrm{Cu}$ (II) dilakukan dengan variasi $\mathrm{pH}$ untuk mendapatkan penyerapan konsentrasi $\mathrm{Cu}$ (II) yang maksimum. Derajat keasaman $(\mathrm{pH})$ larutan ion $\mathrm{Cu}(\mathrm{II})$ divariasikan pada $\mathrm{pH}$ 2 - 8 pada konsentrasi ion $\mathrm{Cu}(\mathrm{II}) 100 \mu \mathrm{g} / \mathrm{L}$, 
waktu kontak 12 jam, dan temperatur selulosa-dietilentriamina ditunjukkan pada larutan $30^{\circ} \mathrm{C}$. Pengaruh variasi $\mathrm{pH}$ pada Gambar 6

pengikatan ion $\mathrm{Cu}(\mathrm{II})$ oleh lapisan pengikat

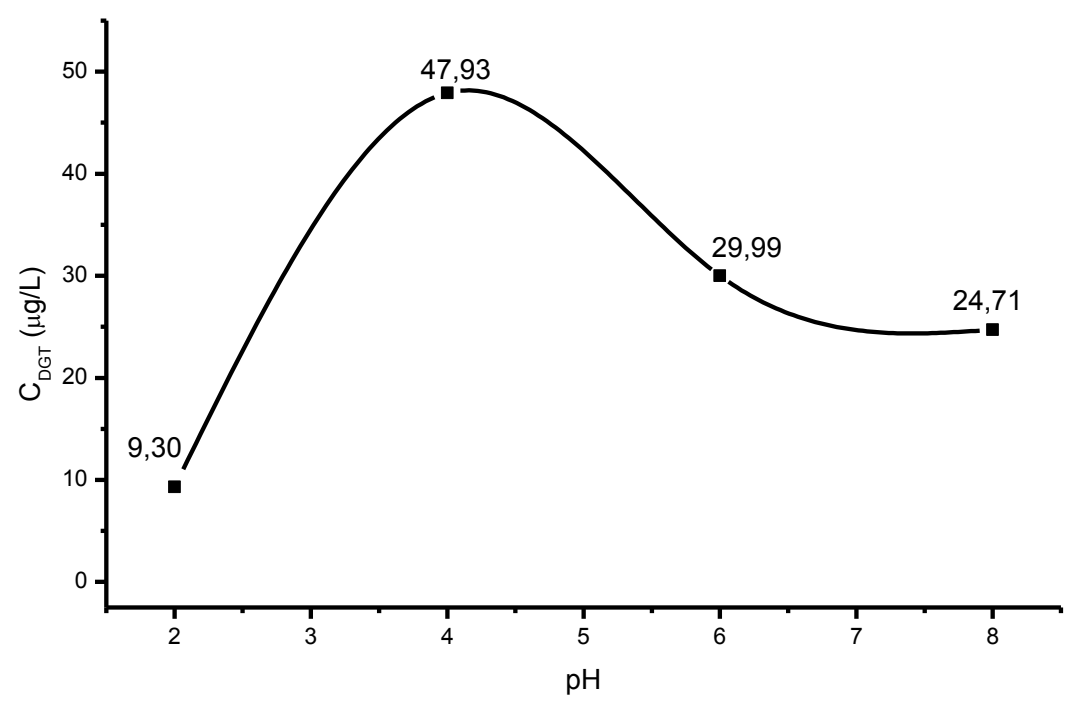

Gambar 6. Pengaruh pH Terhadap Konsentrasi $\mathrm{Cu}(\mathrm{II})$ pada Lapisan Pengikat Selulosa-dietilentriamina dengan Lapisan Difusi Gel Poliakrilamida.

Berdasarkan Gambar 6 terlihat bahwa terjadi peningkatan konsentrasi logam $\mathrm{Cu}(\mathrm{II})$ mencapai maksimum pada $\mathrm{pH} 4$ dengan menggunakan gel lapisan difusi poliakrilamida dengan perolehan konsentrasi maksimum ion $\mathrm{Cu}$ (II) 47,93 $\mu \mathrm{g} / \mathrm{L} \mathrm{L}$. Pada $\mathrm{pH} 2$, terlihat hanya sedikit ion $\mathrm{Cu}$ (II) yang terikat pada lapisan pengikat karena gugus amina pada selulosa dietilentriamina terprotonasi oleh ion $\mathrm{H}^{+}$ sehingga sulit untuk mengikat ion $\mathrm{Cu}(\mathrm{II})$. Hal ini menyebabkan efisiensi pengikatan $\mathrm{Cu}(\mathrm{II})$ oleh lapisan pengikat menjadi berkurang. Rerata konsentrasi ion $\mathrm{Cu}(\mathrm{II}) \mathrm{pH} 2$ pada lapisan pengikat selulosa -dietilentriamina diperoleh 9,30 $\mu \mathrm{g} / \mathrm{L}$ dengan menggunakan gel difusi poliakrilamida.

Pengikatan ion $\mathrm{Cu}(\mathrm{II})$ oleh lapisan pengikat meningkat dan mencapai maksimum $\mathrm{pH} 4$ karena pada $\mathrm{pH}$ ini semakin banyak jumlah ion $\mathrm{Cu}(\mathrm{II})$ yang terikat baik secara ionik dengan gugus $-\mathrm{OH}$ dari selulosa maupun dengan gugus $-\mathrm{NH}$ dari dietilentriamina yang kaya akan pasangan elektron bebas.

Pada $\mathrm{pH} \quad 6$ terjadi penurunan konsentrasi hingga $\mathrm{pH}$ 8. Pada $\mathrm{pH}$ 8, adanya ion-ion $\mathrm{OH}^{-}$akan membuat sebagian ion $\mathrm{Cu}$ (II) yang ada dalam larutan membentuk $\mathrm{Cu}(\mathrm{OH})_{2}$ dengan ukuran molekul besar sehingga sulit untuk 
memasuki lapisan gel difusi. Alasan lainnya, Shen et al. (2009) menyatakan bahwa kompleks sangat tidak stabil antara ion logam $\mathrm{Cu}$ dan atom $\mathrm{N}$ dari lapisan pengikat selulosa-dietilentriamina saat $\mathrm{pH}>4,5$.

\section{KESIMPULAN}

Berdasarkan hasil penelitian dapat disimpulkan bahwa konsentrasi timbal dalam larutan maupun air laut dapat diukur dengan metode DGT menggunakan gel lapisan pengikat logam selulosa dietilentriamina, kondisi optimum pada pengukuran $\mathrm{Cu}$ (II) menggunakan selulosa dietilentriamina setelah waktu kontak hingga12 jam, konsentrasi maksimum hingga $1000 \mu \mathrm{g} / \mathrm{L}$ dan pada maksimum pada $\mathrm{pH} 4$.

\section{DAFTAR PUSTAKA}

Ahmad R., Rajeev K., and Haseeb S. 2012. Adsorption of $\mathrm{Cu}^{2+}$ from aqueous solution onto iron oxide coated eggshell powder: Evaluation of equilibrium, isotherms, kinetics, and regeneration capacity, Arabian Journal of Chemistry, 5: 353-359.

Chethan, P.D., and B. Vishalakshi. 2015. Synthesis of ethylenediamine modified chitosan microspheres forremoval of divalent and hexavalent ions, International Journal of Biological Macromolecules, 75: 179185.

Czaja W, Romanovicz D., and Brown R. M. 2004. Structural investigations of microbial cellulose produced in stationary and agitated culture, Cellulose, 11: 403-411.
Dahlqvist, R., Zhang, H., Ingri, J. 2002. Performance of the diffusive gradients in thin films technique for measuring $\mathrm{Ca}$ and $\mathrm{Mg}$ in freshwater. Analytica Chimica Acta. 460: 247 - 256.

Denney, S., Sherwood, J., Leyden, J. 1999. In situ measurements of labile $\mathrm{Cu}, \mathrm{Cd}$ and $\mathrm{Mn}$ in river waters using DGT. The Science of the Total Environment. 239: 71-80.

Dunn, R.J.K., Teasdale, P.R., Warnken, J., Jordan, M.A. 2007. Evaluation of the in situ, time-integrated DGT technique by monitoring changes in heavy metal concentrations in estuarine waters. Environmental Pollution, 148: 213 - 220.

Li,W., Teasdale, P.R., Zhang, S. 2003. Application of a Poly(4styrenesulfonate) Liquid Binding Layer for Measurement of $\mathrm{Cu}^{2+}$ and $\mathrm{Cd}^{2+}$ with the Diffusive Gradients in ThinFilms Technique. Analytical Chemistry, 75: $2578-2583$.

Mojsilovic O., McLaren R.G., \& Condron, L.M. 2011. Modelling arsenic toxicity in wheat: Simultaneous application of diffusive gradients in thin films to arsenic and phosphorus in soil. Environmental Pollution. 159: 29963002.

Morford, J., Kalnejaisa L., Martina W., Francoisa R., Karleb I.M. 2003. Sampling marine pore waters for $\mathrm{Mn}$, $\mathrm{Fe}, \mathrm{U}, \mathrm{Re}$ and Mo: modifications on diffusional equilibration thin film gel probes, Journal of Experimental Marine Biology and Ecology, 285: 85- 103.

Scally, S., Davison, W., Zhang, H. 2006. Diffusion coefficients of metals and metal complexes in hydrogels used in diffusive gradients in thin films, 
Analytica Chimica Acta. 558: 222229.

Shaaban, A.F, Fadel, D.A., Mahmouda A.A., Elkomy, M.A., Elbahy, S.M. 2014. Synthesis of a new chelating bearing amidoxime group for adsorption of $\mathrm{Cu}(\mathrm{II}), \mathrm{Ni}(\mathrm{II})$ and $\mathrm{Cu}(\mathrm{II})$ by batch and fixed-bed column methods, Journal of Environmental Chemical Engineering, 2: 632-641.

Shen, W., Chen, S., Shi, S. 2009. Adsorption of $\mathrm{Cu}$ (II) and $\mathrm{Pb}$ (II) onto diethylenetriamine - bacterial cellulose. Carbohydrate Polymers. 75: 110-114. 